\title{
Stem cells for cardiac regeneration and possible roles of the transforming growth factor- $\beta$ superfamily
}

\author{
Nanako Kawaguchi \\ Department of Pediatric Cardiology, Tokyo Women's \\ Medical University, Tokyo 162-8666, Japan \\ e-mail: nanako.res@gmail.com
}

\begin{abstract}
Heart failure is a leading cause of death worldwide. Studies of stem cell biology are essential for developing efficient treatments. Recently, we established and characterized c-kitpositive cardiac stem cells from the adult rat heart. Using a MethoCult culture system with a methyl-cellulose-based medium, stem-like left-atrium-derived pluripotent cells could be regulated to differentiate into skeletal/cardiac myocytes or adipocytes with almost $100 \%$ purity. Microarray and pathway analyses of these cells showed that transforming growth factor- $\beta 1$ (TGF- $\beta 1$ ) and noggin were significantly involved in the differentiation switch. Furthermore, TGF- $\beta 1$ may act as a regulator for this switch because it simultaneously inhibits adipogenesis and activates myogenesis in a dose-dependent manner. However, the effect of TGF- $\beta$ varies with developmental stage, dosage, and timing of treatment. In the present review, the findings of recent studies, in particular the use of c-kit-positive cardiac stem cells, are discussed. The effects of the TGF- $\beta$ superfamily on differentiation, especially on adipogenesis and/or myogenesis, have important implications for future regenerative medicine.
\end{abstract}

Keywords: adipogenesis; myogenesis; regenerative medicine; stem cell; TGF- $\beta$ family.

\section{Introduction}

Myocardial infarction is one of the leading causes of death in the Western world $(1,2)$. Heart failure is induced by a reduction in the number of viable cardiac myocytes (3). Stem cell therapy is an advanced technique for supplying cardiac myocytes for cardiac regeneration. Recently established induced pluripotent stem (iPS) cells are considered to be the most useful cell sources because they are autografts with a high ability to differentiate, similar to embryonic stem (ES) cells (4, 5). Adult somatic stem cells have also gained attention, and bone marrow stem cells are being clinically studied (6). Orlic et al. (7) first demonstrated that bone marrow stem cells differentiate into cardiac myocytes to repair an infarcted heart.
However, the ability of bone marrow stem cells to differentiate into cardiac myocytes (8) remains controversial. Contrary to the findings of Orlic et al., Murry et al. (9) reported that bone marrow stem cells fuse to form cardiac myocytes. Nevertheless, bone marrow stem cell therapy has been shown to have positive results (8), and the paracrine effect of stem cells has been suggested to contribute to these positive results (10). In addition to bone marrow stem cells, adipose-derived stem cells have recently been characterized, and their use as a cell source for cell therapy has been encouraged (11-14).

Beltrami et al. and other groups (15-18) observed and isolated resident stem cells from the adult rat heart. They reported that these cells differentiated into cardiac myocytes in vitro and in a myocardial infarct model. The existence of these stem cells and their ability for cardiac differentiation have been widely discussed (6, 19-21). Cardiac stem cells were isolated from mouse, rat, dog, and human hearts on the basis of the presence of cell surface antigens, namely, stem cell antigen-1 (Sca-1) (22, 23), ATP-binding casette, sub-family G, member 2 (Abcg2) (24, 25), and c-kit (15). Spheroid-forming cells derived from endomyocardial biopsy specimens have also been used as cell sources for regenerative medicine $(16,26)$. Islet-1-positive cells, a distinct population of cardiac progenitors, were identified in embryonic and neonatal mouse and human hearts. However, their existence in the adult heart has not yet been confirmed $(27,28)$.

Cardiac medicine, especially cardiac myocyte recovery, is the most urgent and important area of regenerative medicine; its effectiveness depends on the level of recovery attained. Cardiac stem cells (CSCs) are believed to supply newly formed myocytes for the repair of defective or dying cardiac myocytes (16). If CSCs exist in an adult heart, a basic study of these stem cells will contribute greatly to future regenerative medicine. It is important to determine how stem cells maintain their stemness and differentiate into cardiac myocytes, and to identify the other functions that they perform for maintaining heart function. Therefore, researchers have been interested in CSCs existing in the adult heart. c-kitpositive CSCs have been reported to exhibit all the characteristics of stemness, such as clonogenicity, self-renewability, and multipotency. Therefore, CSCs could be the most appropriate candidates for future cardiac regenerative medicine $(29,30)$. In our studies, we focused on these cells by using adult rat hearts owing to their small size and ease of handling. However, a comparison between the animal model and the human heart is necessary. 


\section{c-kit-positive CSCs}

We examined a long-term culture of c-kit-positive CSCs, which have been reported to maintain stemness by overcoming senescence (15). We found that these cells sustained proliferation for more than 50 passages; somatic cells, such as fibroblasts and other differentiated cells usually terminate division after this number of passages. We performed reverse transcriptasepolymerase chain reaction (RT-PCR) analyses to study c-kitpositive CSCs in terms of stemness and multipotency. We revealed the presence of various cell-specific genes, indicating that the cells were heterogeneous. Not only did they display three cardiac lineages (cardiac myocytes, smooth muscle cells, and endothelial cells) but they also showed expression of other cell types, such as preadipocyte and skeletal/cardiac muscle lineages, at various levels after long-term culture (31). Two of 11 CSC-bulk cultures (CSC-BCs) showed this [preadipocyte and skeletal/cardiac myocyte (Myo)] phenotype. We therefore classified these cells as mesenchymal stem cells (MSCs). Six of the 11 CSC-BCs showed the characteristics of adipocytes (Adi). On the basis of these results, c-kit- positive CSCs seem to be similar to MSCs. Gambini et al. (32) reported that c-kit-positive cells exhibited mesenchymal markers and preferred to commit to cardiovascular cells. However, subtle variations in methods or the consistency of the medium used among research groups can contribute to different results.

Recently, Tallini et al. (33) established enhanced green fluorescent protein (EGFP) knock-in mice that express EGFP at the c-kit locus. By focusing on c-kit expression in the heart during the embryonic to adult stages, these researchers reported that c-kit-positive cells appeared in the cardiac region around embryonic day 14.5 , peaked after $0-5$ postnatal days in the atrioventricular region, and were rare in the adult rat heart. Using fluorescence-activated cell sorting (FACS), we observed a c-kit population (Figure 1). The cells obtained might be classified as low-c-kit-expressing cells on the basis of their characteristics. Therefore, differences in c-kit expression may induce the different effects (high-c-kit-positive cells may be cardiac progenitors, and low-c-kit-positive cells may be similar to MSCs).

c-kit is one of the markers of stem cells in the bone marrow and/or of hematogenesis, and it is circulated within the


Figure 1 c-kit-positive cell population visualized by flow cytometry analysis.

The small cells, the adult heart cells from which the cardiac myocytes were removed by centrifugation, were treated with the c-kit antibody and a secondary antibody, or a secondary antibody alone. Cells were subjected to forward scatter (FS) and side scatter (SS) analysis. Within the A region, a higher percentage of c-kit-positive cells was observed following treatment with the c-kit antibody and a secondary antibody than with the secondary antibody alone. 
body through the blood. The role of c-kit has frequently been investigated using $W$ mice, which have a mutated c-kit protein. Using the tract of bone marrow cells from $W$ and wildtype mice, Fazel et al. (34) demonstrated that c-kit-positive cells may play a role in the secretion of cytokines involved in the angiogenesis of infarcted hearts. The mechanism underlying the involvement of c-kit in myocyte differentiation remains unclear. Recently, Li et al. (35) reported that c-kit functioned in the terminal differentiation of cardiac myocytes. Meanwhile, Pouly et al. (36) observed a heterogeneous population of c-kit-positive cells, similar to mast cells, in the adult rat heart.

\section{Stem cells common to skeletal myocytes and cardiac myocytes}

The regenerative capacity of c-kit-positive cardiac cells from different parts of adult rat hearts has been discussed. Beltrami et al. (15) reported that the atrium had a higher percentage of stem cells than the other parts of the heart. We previously isolated and characterized c-kit-positive cell populations from different parts of the heart, including the left atrium, right atrium, left ventricle, right ventricle, septum, and apex. While the cells from all of these parts proliferated, the c-kitpositive cells isolated from the left atrium grew strongly and for a prolonged period. Unique skeletal-muscle-like spindleshaped cells appeared in the culture of left-atrium-derived c-kit-positive cells when they became confluent or were grown in myocyte-differentiation-inducing medium $(31,37)$. We named these cells left-atrium-derived pluripotent cells (LA-PCs) because of their ability to differentiate into many cell types. We focused on two important transcription factors (TFs) - myogenin and GATA-binding protein 4 (GATA4) and their functions. Myogenin is one of the specific skeletal myocyte-inducing TFs (38), while GATA4 is one of the TFs necessary for inducing cardiac myocytes from heart-derived fibroblasts (39). Some of the cloned LA-PCs were positive for both GATA4 and myogenin. These TFs influenced each other and synergistically controlled the cardiac-specific atrial nitric protein promoter (37). Moreover, they could differentiate into cardiac and skeletal muscle cells. Carcinogenic P19 cells showed similar differentiation abilities (40). Mesoangioblasts, which can differentiate into skeletal myocytes, vascular cells, and other mesodermal cells, revealed similar characteristics. Skeletal and cardiac muscles have the same origin, namely, the mesoderm, indicating that the stem cell origin may be shared (41). Interestingly, these mesoangioblasts are derived from the dorsal aorta or vessel (42), and express KIT, CD34, and Flk- 1 (43). Our microarray data revealed that LA-PCs and other CSC-BCs also express these genes (unpublished results). Using cardiac biopsy, Minasi et al. (41) isolated mesoangioblasts from the human heart, similar to the CSCs observed by Beltrami et al. (15).

Takebayashi-Suzuki et al. detected MyoD-positive cells in the avian embryonic heart (44). However, the existence of these cells in mammalian adult hearts has not been investigated. LA-PCs are not anticipated to express MyoD or myogenin in vivo; we believe that these cells exist in the immature heart because no studies have demonstrated the existence of MyoD/GATA4 double-positive cells in the adult rat heart. We propose that, on migration from their niche (in vivo) or when cultured in vitro, some of these cells become myogenin/GATA4 positive. Therefore, they may not have a normal nature. Other CSC-BCs (CSC-BC8) were also observed to be myogenin positive, suggesting that CSCs can be myogenin positive under certain culture conditions, and that this somehow reflects their in vivo nature. The finding that LA-PCs can differentiate into cardiac and skeletal myocytes differs from previous results obtained using chicken hearts. These studies showed that MyoD and myogenin were expressed and enhanced by endothelin treatment (endothelin is a positive regulator for induction of Purkinje cells) in vivo and in vitro $(44,45)$. Furthermore, the mechanism of differentiation was distinct from that of Myo; the induced Purkinje cells expressed myogenin, but not Myogenic factor 5 (Myf5) (44), which was detected in Myo.

Wojakowski et al. (46) demonstrated that mononuclear cells in peripheral blood expressed CD34/C-X-C chemokine receptor type $4\left(\mathrm{CXCR}^{+}\right), \mathrm{CD} 34 / \mathrm{CD} 117^{+}$, and c-met ${ }^{+}$stem cells (human); these cells could act as progenitors and express early cardiac myocyte specific markers [GATA4, Myocyte enhancer factor $\mathrm{C}(\mathrm{MEF} 2 \mathrm{C})]$, skeletal muscle progenitor markers (Myf5, MyoD, myogenin), and an endothelin-specific marker (VE-cadherin). These findings are similar to those reported for LA-PCs, and indicate the possibility of common progenitors for cardiac and skeletal myocytes. In acute myocardial infarcted patients, CXCR4 receives the signal from stromal cell derived factor-1 (SDF-1) in the bone marrow through chemoattraction, and this is spread through the blood. These stem-like cells function to repair the damage to infarcted hearts. Therefore, the cytokines are important for inducing these signals (46). Our microarray data indicated that LA-PCs express CXCR4 in undifferentiated (UND) cells, Adi, and Myo, but express CD34 only in differentiated cells (Adi and Myo) (unpublished data). Using RT-PCR, we observed SDF-1 expression by RT-PCR (data not shown).

Cardiac/skeletal myocytes differentiate from LA-PCs because common TFs, such as Mef2, not only undergo regulation during early development (47) but can also function when adult somatic stem cells differentiate into Myo. Interestingly, GATA4 and bHLH proteins (MyoD) synergistically affect fibroblast growth factor (FGF) gene expression (48).

We anticipated that LA-PCs might constitute a useful tool for a differentiation model, similar to $\mathrm{P} 19$ or $\mathrm{C} 2 \mathrm{C} 12$ cells, which differentiate into skeletal myocytes and other mesenchymal cells. LA-PCs can differentiate into Adi or Myo with purity. Therefore, we used these cells to identify the relevant differentiation switch.

\section{Microarray and pathway analysis}

LA-PCs grown in growth medium containing embryonic grade fetal bovine serum, leukemia inhibitory factor (LIF), 


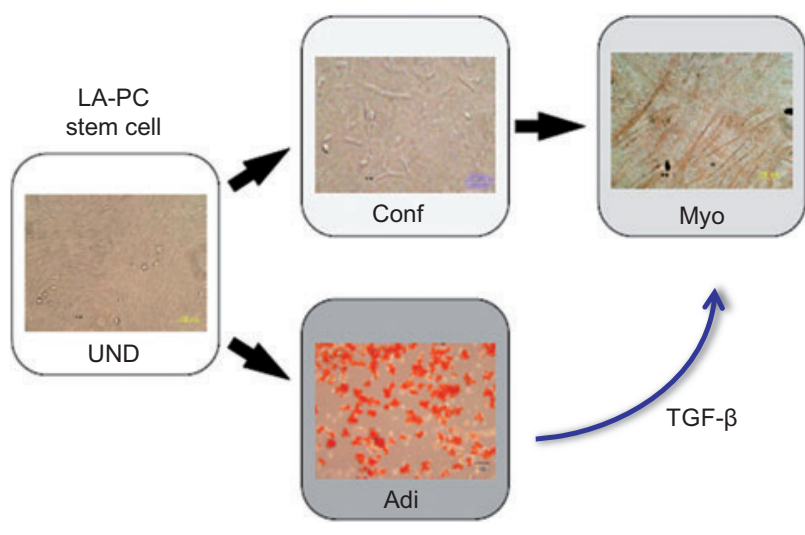

Figure 2 LA-PCs comprise a mixed population of stem cells and the progenitors for skeletal/cardiac myocytes (Myo) or adipocytes (Adi).

Differentiated Myo were troponin I positive, and differentiated Adi were stained by oil red. The TGF- $\beta$ superfamily was significantly involved in the differentiation switch. Figure reproduced from reference (49) with permission.

and erythropoietin were considered to be UND (Figure 2). We previously observed some fractionated cells that preferred to differentiate purely into mature Adi in the MethoCult medium [supplied by Stem Cell Technologies (Vancouver, BC, Canada), supplemented with interleukin (IL)-3, IL-6, and stem cell factor (SCF)]. However, when grown in the myocyte differentiation medium or grown to be confluent, the same cells differentiated purely into Myo. LA-PCs comprise a mixed population, consisting of UND cells and the progenitors for Adi and/or Myo (Figure 2). We used microarray analyses for these three cell groups (UND, Adi, and Myo) to identify the signal transduction pathway or the signal molecule responsible for the differentiation switch between Adi and Myo. We observed that the striated muscle contraction signal was upregulated in Myo, while adipogenesis and the fatty acid metabolic pathway were upregulated in Adi (49). Therefore, we confirmed that our system reflected the differentiation. We also demonstrated the significance of the transforming growth factor- $\beta$ (TGF- $\beta$ ) pathway in signal transduction. Furthermore, we revealed that TGF- $\beta 1$ simultaneously induced myogenesis and inhibited adipogenesis in a dose-dependent manner (49). These findings were supported by additional data; for example, TGF-R1 expression, as measured by RT-PCR, was inhibited in Adi, which is consistent with the positive effect of TGF- $\beta 1$ on myogenesis and its negative effect on adipogenesis. Furthermore, using RT-PCR, we demonstrated that Fst expression was upregulated in Myo but downregulated in Adi, in accordance with the microarray data (49). Our data also revealed that the expression of frizzled (fzd) is downregulated in Adi (49), suggesting the involvement of a Wnt signal. Crosstalk between Wnt and TGF- $\beta$ is possible $(50,51)$. Thus, a detailed investigation of the molecules involved in these differentiation pathways is required.

\section{Effect of TGF- $\beta$ on myogenesis and adipogenesis}

We previously observed that TGF- $\beta 1$ may act as a positive regulator for myogenesis. However, using the myoblast cell line $\mathrm{C} 2 \mathrm{C} 12$, TGF- $\beta 1$ has also been shown to act as a negative regulator for myogenesis (52). In this response, Smad3 activation was mediated. By contrast, Smad7 activation affects myogenesis (53) because of the inhibitory function of Smad7 toward TGF- $\beta$.

In our system, TGF- $\beta$ acted as a positive regulator for myogenesis. The different functions may reflect different doses of TGF- $\beta$ because the function is dose dependent. We anticipate that differences in the stage of stemness may also affect the outcome. TGF- $\beta$ regulates not only adult stem cells but also primitive stem cells, such as ES cells to maintain stemness $(54,55)$. The dose and timing of the treatment can induce completely different results (49). The effect of TGF- $\beta$ also varies according to the cell source. In embryonic myoblast differentiation, TGF- $\beta$ acts positively (56). However, in more mature types of myoblasts, such as C2C12, TGF- $\beta$ acts negatively $(57,58)$. The negative effect of TGF- $\beta$ signaling on adipogenesis may operate through Smad3/4 binding with CCAAT/enhancer-binding protein TFs (59). The concise signal transductions, including Smad molecules, are described by Diike and Heiden (60) and Derynck and Miyazono (61).

LA-PCs are considered primitive with respect to stemness. Therefore, TGF- $\beta 1$ acts as a positive regulator for myogenesis. TGF- $\beta$ can work positively at the first myocyte induction, and negatively at subsequent myocyte inductions. Recently, it has been suggested that the epithelial-mesenchymal transition (EMT) may contribute to the switch. TGF- $\beta$ was noted to play an important role in EMT for myofibrosis of epithelial cells. EMT is also very important for inducing multiple organogeneses in the embryo (62). This type of transition induces pluripotent cells and may contribute to cancer formation (63). TGF- $\beta$ can regulate cell cycle proteins, such as cyclin-dependent kinase (CDK2), and the inhibitor of differentiation (Id) (60). Altogether, these findings indicate that TGF- $\beta$ can induce certain cells, such as endothelial cells and immature c-kit-positive cells to be mesenchymal cells.

\section{Effect of Rho GTPase signaling on the switch between adipogenesis and myogenesis}

On the other hand, Rho GTPase signaling has been reported to be involved in the switch between adipogenesis and myogenesis (64). Rho GTPase was downregulated in both Myo and Adi in our microarray results (data not shown). However, a two-fold decrease in Myo and an eight-fold decrease in Adi were observed in both 3D-Gene analyses (Toray, Tokyo, Japan) and Agilent chips (Agilent Technologies, Santa Clara, CA, USA). The magnitude of expression can contribute to the switch. 


\section{Noggin and cardiac myocytes}

We previously used a MethoCult culture to obtain small portions of beating cardiac myocytes in vitro. However, we failed to acquire sufficient quantities. Therefore, we selected other TGF- $\beta$ superfamily members for regulation in our microarray experiments. We observed that noggin was downregulated; this downregulation was confirmed by RT-PCR. Interestingly, when we added noggin to the MethoCult culture, we observed a significant effect on the induction of cardiac myocytes, but not on the induction of skeletal myocytes (Figure 3). Noggin was previously reported to act as an activator for cardiac myogenesis (65). TGF- $\beta$ is expressed during early cardiac development (50), while bone morphogenic protein (BMP)-2
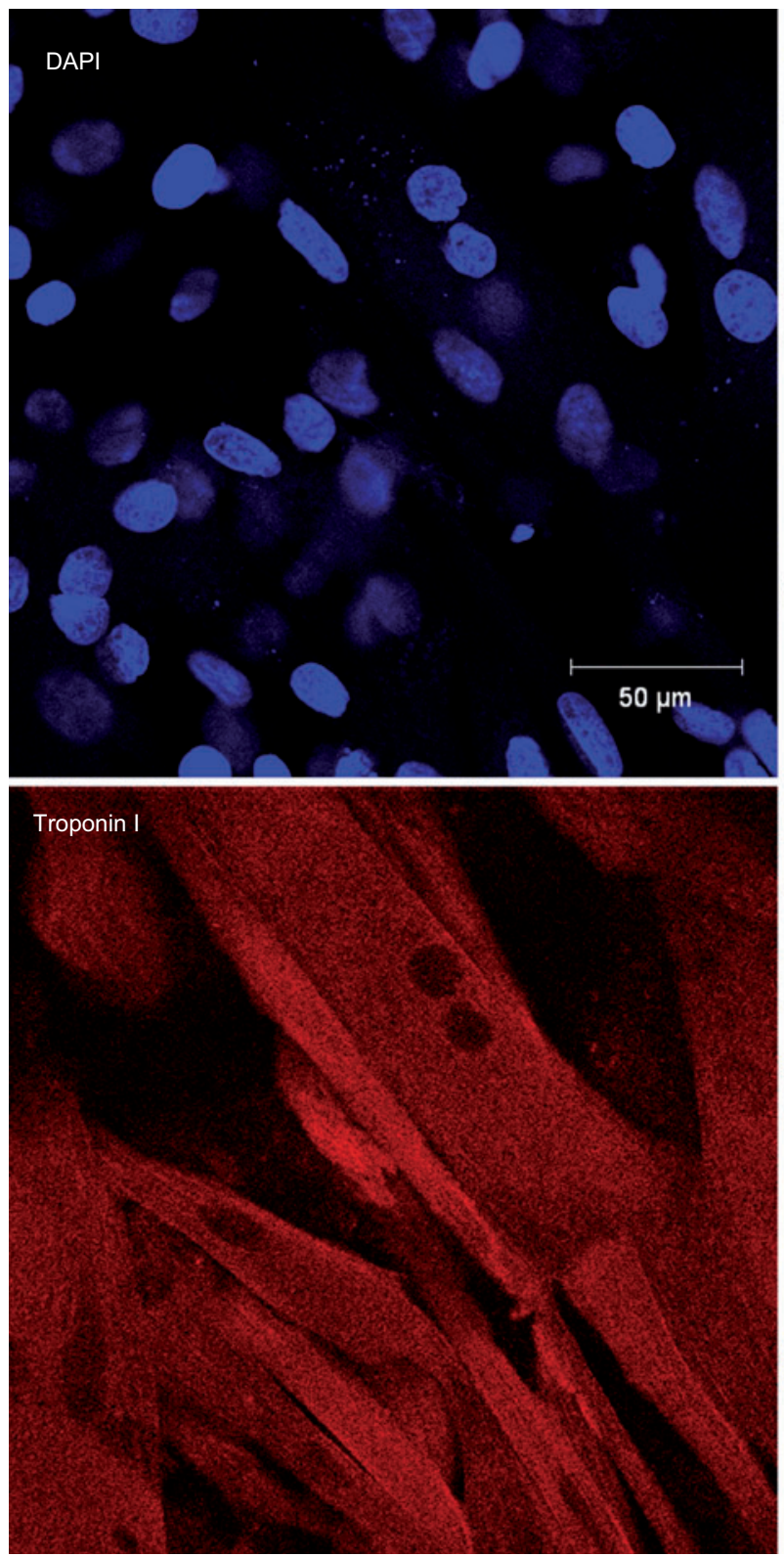

and BMP-4 play key roles in mesoderm morphogenesis. Thus, noggin and BMP groups and TGF- $\beta$ are important in the regulation of mesoderm-originated cells. Moreover, the balance and timing of the treatment can greatly alter the cell phenotypes. Recently, microRNAs have also been shown to be regulators for cardiac myogenesis $(66,67)$. Other regulators of CSCs will be discussed elsewhere $(68,69)$.

\section{Expert opinion}

The molecular biological approach of using c-kit-positive CSCs for differentiation or for maintenance of stemness provides knowledge for future applications, such as drug


Figure 3 Noggin could induce many mature cardiac myocytes.

LA-PCs were cultured in MethoCult medium with noggin. The differentiated cells were stained with cardiac myocyte marker, troponin I, and $\alpha$-sarcomeric actinin. Figure reproduced from reference (49) with permission. 
discovery. Furthermore, combining the findings of different studies may facilitate the development of new applications. Discussion and exchange of information will contribute to rapid progress in this field.

LA-PCs are c-kit-positive cells that are derived from adult atrium tissue and that differentiate into three cardiac lineages (cardiomyocytes, endothelial cells, and smooth muscle cells), and also into Myo and Adi. Furthermore, in MethoCult medium, some fractions of the cells are able to differentiate into either Myo or Adi with almost $100 \%$ purity. Using microarray analysis, we compared the expression profiles of the three cell states (UND, Adi, and Myo) and demonstrated that the TGF- $\beta$ superfamily acted as a differentiation switch. We also revealed that noggin enhanced differentiation into cardiac myocytes. The systematic approach of using microarray and signal transduction analyses proved successful in identifying the significant molecules for differentiation. Combining our results with those reported by other researchers may facilitate the isolation of a high number of cardiac myocytes able to function in regenerative medicine and the development of new drugs for heart failure. Moreover, unification of lists of signaling molecules and differentiated cell states will enable the differentiation necessary for repairing damage to the heart and other tissues.

\section{Outlook}

We observed similarities between LA-PCs and some other adult somatic stem cells, including P19 carcinoma cells, mesoangioblasts, and mononuclear cells $\left(\mathrm{CD} 34 / \mathrm{CXCR} 4^{+}\right)$. However, we also observed differences. Our results indicate that the TGF- $\beta$ family can regulate cell fates. Further studies are required to determine whether TGF- $\beta$ can change the cell fate of other somatic stem cells, and to clarify the TGF- $\beta$ signal transduction pathway. Our studies were limited by the use of rat cells; therefore, we were unable to identify the key molecules involved in the upregulation and downregulation of the TGF- $\beta$ pathway. Identification of the appropriate LA-PCs in vivo would facilitate a new regenerative approach.

\section{Highlights}

We established left-atrium-derived pluripotent cells, and demonstrated their importance as a tool for identifying the signal transduction pathway involved in the differentiation switch into skeletal/cardiac myocytes or adipocytes. We further revealed that the transforming growth factor- $\beta$ superfamily is significantly involved in this switch.

\section{Acknowledgments}

This work was supported by the Program for Promoting the Establishment of Strategic Research Centers, Special Coordination Funds for Promoting Science and Technology, Japan and a Grantin-Aid for Scientific Research (A) (Japan).

\section{References}

1. Braunwald E. The Denolin lecture. Congestive heart failure: a half century perspective. Eur Heart J 2001; 22: 825-36.

2. Braunwald E, Bristow M. Congestive heart failure: fifty years of progress. Circulation 2000; 102: 14-23.

3. Braunwald E, Pfeffer M. Ventricular enlargement and remodeling following acute myocardial infarction: mechanisms and management. Am J Cardiol 1991; 68: 1D-6D.

4. Takahashi K, Yamanaka S. Induction of pluripotent stem cells from mouse embryonic and adult fibroblast cultures by defined factors. Cell 2006; 126: 663-76.

5. Takahashi K, Tanabe K, Ohnuki M, Narita M, Ichisaka T, Tomoda K, Yamanaka S. Induction of pluripotent stem cells from adult human fibroblasts by defined factors. Cell 2007; 131 : 861-72.

6. Rubart M, Field L. Stem cell differentiation: cardiac repair. Cells Tissues Organs 2008; 188: 202-11.

7. Orlic D, Kajstura J, Chimenti S, Jakonik I, Anderson SM, Li B, Pickel J, Mckay R, Nadal-Ginard B, Bodine DM, Leri A, Anversa $\mathrm{P}$. Bone marrow cells regenerate infarcted myocardium. Nature 2001; 410: 701-5.

8. Tousoulis D, Briasoulis A, Antoniades C, Stefanadi E, Stefanadis C. Heart regeneration: what cells to use and how? Curr Opin Pharmacol 2008; 8: 211-8.

9. Murry C, Soonpaa M, Reinecke H, Nakajima H, Nakajima HO, Rubart M, Pasumarthi KB, Virag JI, Bartelmez SH, Poppa V, Bradford G, Dowell JD, Williams DA, Field L. Hematopoietic stem cells do not differentiate into cardiac myocytes in myocardial infarcts. Nature 2004; 428: 664-8.

10. Uemura R, Xu M, Ahmad N, Ashraf M. Bone marrow stem cells prevent left ventricular remodeling of ischemic heart through paracrine signaling. Circ Res 2006; 98: 1414-21.

11. Planat-Bénard V, Menard C, André M, Puceat M, Perez A, Garcia-Verdugo JM, Pénicaud L, Casteilla L. Spontaneous cardiomyocyte differentiation from adipose tissue stroma cells. Circ Res 2004; 94: 223-9.

12. Yamada Y, Wang X, Yokoyama S, Fukuda N, Takakura N. Cardiac progenitor cells in brown adipose tissue repaired damaged myocardium. Biochem Biophys Res Commun 2006; 342: 662-70.

13. Gimble J, Katz A, Bunnell B. Adipose-derived stem cells for regenerative medicine. Circ Res 2007; 100: 1249-60.

14. Madonna R, Geng Y, De Caterina R. Adipose tissue-derived stem cells: characterization and potential for cardiovascular repair. Arterioscler Thromb Vasc Biol 2009; 29: 1723-9.

15. Beltrami A, Barlucchi L, Torella D, Baker M, Limana F, Chimenti S, Kasahara H, Rota M, Musso E, Urbanek K, Leri A, Kajstura J, Nadal-Ginard B, Anvarsa P. Adult cardiac stem cells are multipotent and support myocardial regeneration. Cell 2003; 114: 763-76.

16. Barile L, Messina E, Giacomello A, Marbán E. Endogenous cardiac stem cells. Prog Cardiovasc Dis 2007; 50: 31-48.

17. Torella D, Indolfi C, Goldspink D, Ellison G. Cardiac stem cellbased myocardial regeneration: towards a translational approach. Cardiovasc Hematol Agents Med Chem 2008; 6: 53-9.

18. Bergmann O, Bhardwaj RD, Bernard S, Zdunek S, BarnabéHeider F, Walsh S, Zupicich J, Alkass K, Buchholz BA, Druid H, Jovinge S, Frisén J. Evidence for cardiomyocyte renewal in humans. Science 2009; 324: 98-102.

19. Anversa P, Kajstura J, Leri A, Bolli R. Life and death of cardiac stem cells: a paradigm shift in cardiac biology. Circulation 2006; 113: 1451-63. 
20. Anversa P, Leri A, Rota M, Hosoda T, Bearzi C, Urbanek K, Kajstura J, Bolli R. Concise review: stem cells myocardial regeneration and methodological artifacts. Stem Cells 2007; 25 : 589-601.

21. Guan K, Hasenfuss G. Do stem cells in the heart truly differentiate into cardiomyocytes? J Mol Cell Cardiol 2007; 43: 377-87.

22. Oh H, Bradfute S, Gallardo TD, Nakamura T, Gaussin V, Mishina Y, Pocius J, Micheal LH, Behringer RR, Garry DJ, Entman ML, Schneider MD. Cardiac progenitor cells from adult myocardium: homing differentiation and fusion after infarction. Proc Natl Acad Sci USA 2003; 100: 12313-8.

23. Matsuura K, Nagai T, Nishigaki N, Oyama T, Nishi J, Wada H, Sano M, Toko H, Akazawa H, Sato T, Nakaya H, Kasanuki H, Komuro I. Adult cardiac Sca-1-positive cells differentiate into beating cardiomyocytes. J Biol Chem 2004; 279: 11384-91.

24. Martin C, Meeson A, Robertson SM, Hawke TJ, Richardson JA, Bates S, Goetsch SC, Gallardo TD, Garry DJ. Persistent expression of the ATP-binding cassette transporter Abcg2 identifies cardiac SP cells in the developing and adult heart. Dev Biol 2004; 265: 262-75.

25. Pfister O, Oikonomopoulos A, Sereti KI, Sohn RL, Cullen D, Fine GC, Monquet F, Westerman K, Liao R. Role of the ATPbinding cassette transporter Abcg2 in the phenotype and function of cardiac side population cells. Circ Res 2008; 103: 825-35.

26. Smith R, Barile L, Cho H, Leppo MK, Hare JM, Messina E, Giacommello A, Abraham MR, Marban E. Regenerative potential of cardiosphere-derived cells expanded from percutaneous endomyocardial biopsy specimens. Circulation 2007; 115: 896-908.

27. Laugwitz K, Moretti A, Lam J, Gruber P, Chen Y, Woodard S, Lin LZ, Cai CL, Lu MM, Reth M, Platoshyn O, Yuan JX, Evans S, Chien KR. Postnatal isl1+ cardioblasts enter fully differentiated cardiomyocyte lineages. Nature 2005; 433: 647-53.

28. Moretti A, Caron L, Nakano A, Lam JT, Bernshausen A, Chen Y, Qyang Y, Bu L, Sasaki M, Martin-Puig S, Sun Y, Evans SM, Laugwitz KL, Chien KR. Multipotent embryonic is11+ progenitor cells lead to cardiac smooth muscle and endothelial cell diversification. Cell 2006; 127: 1151-65.

29. Torella D, Ellison G, Méndez-Ferrer S, Ibanez B, Nadal-Ginard B. Resident human cardiac stem cells: role in cardiac cellular homeostasis and potential for myocardial regeneration. Nat Clin Pract Cardiovasc Med 2006; 3: Suppl 1: 8-13.

30. Ellison G, Torella D, Karakikes I, Nadal-Ginard B. Myocyte death and renewal: modern concepts of cardiac cellular homeostasis. Nat Clin Pract Cardiovasc Med 2007; 4: 52-9.

31. Miyamoto S, Kawaguchi N, Ellison G, Matsuoka R, Shin'oka T, Kurosawa H. Characterization of long-term cultured c-kitpos cardiac stem cells (CSCs) derived from adult rat hearts. Stem Cells Dev 2010; 19: 105-16.

32. Gambini E, Pompilio G, Biondi A, Alamanni F, Capogrossi MC, Agrifoglio M, Pesce M. c-kit+ cardiac progenitors exhibit mesenchymal markers and preferential cardiovascular commitment. Cardiovasc Res 2011; 89: 362-73.

33. Tallini Y, Greene K, Craven M, Spealman A, Breitbach M, Smith J, Fisher PJ, Steffey M, Hesse M, Doran RM, Woods A, Singh B, Yen A, Fleischmann BK, Kotikoff MI. c-kit expression identifies cardiovascular precursors in the neonatal heart. Proc Natl Acad Sci USA 2009; 106: 1808-13.

34. Fazel S, Cimini M, Chen L, Li S, Angoulvant D, Fedak P, Verma S, Weisel RD, Keating A, Li RK. Cardioprotective c-kit ${ }^{+}$cells are from the bone marrow and regulate the myocardial balance of angiogenic cytokines. J Clin Invest 2006; 116: 1865-77.
35. Li M, Naqvi N, Yahiro E, Liu K, Powell PC, Bradley WE, Martin DI, Graham RM, Dell'Italia LJ, Husain A. c-kit is required for cardiomyocyte terminal differentiation. Circ Res 2008; 102: 677-85.

36. Pouly J, Bruneval P, Mandet C, Proksch S, Peyrard S, Amrein C, Bousseaux V, Guillemain R, Deloche A, Fabiani JN, Menasché P. Cardiac stem cells in the real world. J Thorac Cardiovasc Surg 2008; 135: 673-8.

37. Hasan MK, Komoike Y, Tsunesumi S, Nakao R, Nagao H, Matsuoka R, Kawaguchi N. Myogenic differentiation in atriumderived adult cardiac pluripotent cells and the transcriptional regulation of GATA4 and myogenin on ANP promoter. Genes Cells 2010; 15: 439-53.

38. Olson E. Activation of muscle-specific transcription by myogenic helix-loop-helix proteins. Symp Soc Exp Biol 1992; 46: 331-41.

39. Danalache B, Paquin J, Donghao W, Gyrgorczyk R, Moore JC, Mummery CL, Gutkowska J, Jankowski M. Nitric oxide signaling in oxytocin-mediated cardiomyogenesis. Stem Cells 2007; 25: 679-88.

40. Ieda M, Fu J, Delgado-Olguin P, Vadantham V, Hayashi Y, Bruneau BG, Srivastava D. Direct reprogramming of fibroblasts into functional cardiomyocytes by defined factors. Cell 2010; 142: $375-86$.

41. Minasi MG, Riminucci M, De Angelis L, Borello U, Berarducci B, Innocenzi A, Caprioli A, Sirabella D, Baiocchi M, De Maria R, Borotto R, Jatlnedo T, Broccoli V, Bianco P, Cossu G. The meso-angioblast: a multipotent, self-renewing cell that originates from the dorsal aorta and differentiates into most mesodermal tissues. Development 2002; 129: 2773-83.

42. Tagliafico E, Brunelli S, Bergamaschi A, De Angelis L, Scardigli R, Galli D, Battini R, Bianco P, Ferrari S, Cossu G, Ferrari S. TGF $\beta / B M P$ activate the smooth muscle/bone differentiation programs in mesoangioblasts. J Cell Sci 2004; 117: 4377-88.

43. Galvez BR, Covarello D, Tolorenzi R, Brunelli S, Dellavalle A, Crippa S, Mohammed SA, Scialla L, Cuccovillo I, Molla F, Staszewsky L, Maisano F, Sampaolesi M, Latini R, Cossu G. Human cardiac mesoangioblasts isolated from hypertrophic cardiomyopathies are greatly reduced in proliferation and differentiation potency. Cardiovasc Res 2009; 83: 707-16.

44. Takebayashi-Suzuki K, Pauliks L, Eltsefon Y, Mikawa T. Purkinje fibers of the avian heart express a myogenic transcription factor program distinct from cardiac and skeletal muscle. Dev Biol 2001; 234: 390-401.

45. Takebayashi-Suzuki K, Yanagisawa M, Gourdie RG, Kanzawa $\mathrm{N}$, MIkawa $\mathrm{T}$. In vivo induction of cardiac fiber differentiation by co-expression of preproendothelin and endothelin converting enzyme-1. Development 2000; 127: 3523-32.

46. Wojakowski W, Tendera M, Michalowska A, Majka M, Kucia M, Malanskiewicz K, Wyderka R, Ochala A, Ratajczak MZ. Mobilization of CD34/CXCR4 ${ }^{+}, \mathrm{CD} 34 / \mathrm{CD} 117^{+}$, c-met $^{+}$stem cells, and mononuclear cells expressing early cardiac, muscle, and endothelin markers into peripheral blood in patients with acute myocardial infarction. Circulation 2004; 110: 3213-20.

47. Potthoff M, Olson E. MEF2: a central regulator of diverse developmental programs. Development 2007; 134: 4131-40.

48. Iwahori A, Fraidenraich D, Basilico C. A conserved enhancer element that drives FGF4 gene expression in the embryonic myotomes is synergistically activated by GATA and bHLH proteins. Dev Biol 2004; 270: 525-37.

49. Kawaguchi N, Nakao R, Yamaguchi M, Ogawa D, Matsuoka R. TGF- $\beta$ superfamily regulates a switch that mediates differentiation 
either into adipocytes or myocytes in left atrium derived pluripotent cells (LA-PCS). Biochem Biophys Res Commun 2010; 396: 619-25.

50. Gilbert SF. Developmental biology, $7^{\text {th }}$ ed., Sunderland, MA: Sinauer Associates Inc., 2003.

51. Singh R, Bhasin S, Braga M, Artaza JN, Pervin S, Taylor WE, Krishnan V, Sinha SK, Rajavashisth TB, Jasuja R. Regulation of myogenic differentiation by androgens: cross talk between androgen receptor/ $\beta$-catenin and follistatin/transforming growth factor- $\beta$ signaling pathways. Endocrinology $2009 ; 150$ : 1259-68.

52. Krueger C, Hoffmann FM. Identification of retinoic acid in a high content screen for agents that overcome the anti-myogenic effect of TGF- $\beta 1$. PLoS One 2010; 30; 5: e15511.

53. Miyake T, Alli NS, McDermott CM. Nuclear function of Smad7 promotes myogenesis. Mol Cell Biol 2010; 30: 722-35.

54. Pucceat M. TGF- $\beta$ in the differentiation of embryonic stem cells. Cardiovasc Res 2006; 74: 256-61.

55. Kitisin K, Saha T, Blake T, Golestaneh N, Deng M, Kim C, Tang Y, Shetty K, Mishra B, Mishra L. TGF- $\beta$ signaling in development. Sci STKE 2007; 399: 1-5.

56. Slager HC, van Inzen W, Freund E, van den Eijndon-van Raaij AJM, Mummery CL. Transforming growth factor- $\beta$ in the early mouse embryo: implications for the regulation of muscle formation and implantation. Dev Genet 1993; 14: 212-24.

57. Massague J, Checifetz S, Endo T, Nadal-Ginard B. Type $\beta$ transforming growth factor is an inhibitor of myogenic differentiation. Proc Natl Acad Sci USA 1986; 83: 8206-10.

58. Olson EN, Sternberg E, Hu JS, Spizz G, Wilcox C. Regulation of myogenic differentiation by type $\beta$ transforming growth factor. $\mathrm{J}$ Cell Biol 1986; 103: 1799-805.

59. Choy L, Derynck R. Transforming growth factor- $\beta$ inhibits adipocyte differentiation by Smad3 interacting with CCAAT/enhancer-binding protein $(\mathrm{C} / \mathrm{EBP})$ and repressing C/EBP transactivation function. J Biol Chem 2003; 278: 9609-19.

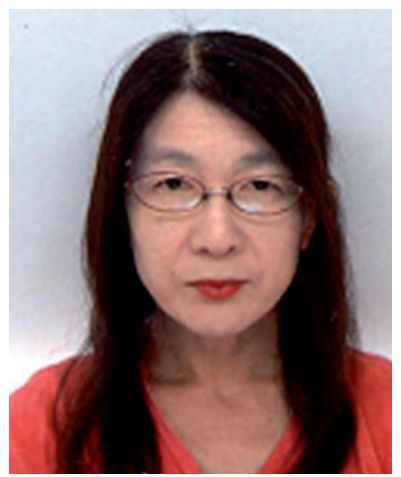

Nanako Kawaguchi, PhD.

I have examined the stemness and differentiation ability of adult-derived cardiac stem cells and induced pluripotent cells (iPS) cells for the past 6 years. I primarily focused on mesenchymal differentiation by using microarray and proteomic analysis. During this research, we observed that stem cells regulate the surrounding cells via soluble factors.

I am further interested in the clinical applications of these stem cells, such as using them as a replacement for damaged tissues or as a source of soluble factors to enhance the viability of the cells within the target tissues (infracted heart).
60. Diike P, Heiden CH, editors. Smad signal transduction: Smads in proliferation, differentiation and disease (proteins and cell regulation), New York: Springer/Netherlands, 2006.

61. Derynck R, Miyazono K, editors. The TGF- $\beta$ family. New York, USA: Cold Spring Harbor Laboratory Press, 2008.

62. Mani SA, Guo W, Liao MJ, Eaton EN, Ayyanan A, Zhou AY, Brooks M, Reinhard F, Zhang CC, Shiptisin M, Campbell LL, Polyak K, Brisken C, Yang J, Weinberg RA. The epithelial-mesenchymal transition generates cells with properties of stem cells. Cell 2008; 133: 704-15.

63. Yang J, Weinberg RA. Epithelial-mesenchymal transition: at the crossroads of development and tumor metastasis. Dev Cell 2008; 14: 818-29.

64. Sordella R, Jiang W, Chen G, Curto M, Settleman J. Modulation of Rho GTPase signalling regulates a switch between adipogenesis and myogenesis. Cell 2003; 113: 147-58.

65. Yuasa S, Itabashi Y, Koshimizu U, Tanaka T, Sugimura K, Kinoshita M, Hattori F, Fukami S, Shimazaki T, Ogawa S, Okano $\mathrm{H}$, Fukuda K. Transient inhibition of BMP signaling by noggin induces cardiomyocyte differentiation of mouse embryonic stem cells. Nat Biotech 2005; 23: 607-11.

66. Ivey KN, Stivastava D. Micro RNAs as regulators of differentiation and cell fate decisions. Cell Stem Cell 2010; 7: 36-41.

67. Wang J, Greene SB, Bonnila-Claudio M, Tao Y, Zhang J, Bai Y, Huang Z, Black BL, Wang F, Martin JF. Bmp signaling regulates myocardial differentiation from cardiac progenitors through a microRNA-mediated mechanism. Dev Cell 2010; 19 : 903-12.

68. Kawaguchi N. Differentiation and survival regulators of adult cardiac derived stem cells. Vitam Horm, 87, Stem cell regulators, Chapter 6: in press.

69. Machida M, Takagaki Y, Matsuoka R, Kawaguchi N. Proteomic comparison of spherical aggregates and adherent cells of cardiac stem cells. Int J Cardiol in press.

Received March 31, 2011; accepted October 25, 2011 